\title{
Feeding and cleaning the city: the role of the urban waterscape in provision and disposal in Vienna during the industrial transformation
}

\author{
Sylvia Gierlinger • Gertrud Haidvogl • Simone Gingrich • \\ Fridolin Krausmann
}

Received: 12 September 2012/ Accepted: 23 March 2013

(C) The Author(s) 2013. This article is published with open access at Springerlink.com

\begin{abstract}
This article presents an integrated socio-ecological perspective on the changing interrelations between Vienna's "urban metabolism" and the river Danube during the industrial transformation in the nineteenth century. During this period of rapid urban population growth and industrial development, the amount of materials and energy used in the city as well as the corresponding outflows of wastes and emissions, that is, the size of urban metabolism, multiplied. These changes in urban metabolism had a profound effect on the relation between city and river. The paper explores the changing role of the Danube and its waterscape for urban supply and urban discharge in the period from 1800 to 1910 . It presents quantitative information on urban resource supply and river transport and discusses the changing function of the river as a major transport route. It investigates urban discharge of waste water and the evolution of a sewer system and discusses how the changing waterscape was reflected in perception and discourse. We find that there was a qualitative change in the transport function of the river. While the river lost importance in the provision of the city with energy it remained crucial for the supply of cereals. Furthermore we observe a general shift from the significance of the river in supplying the city towards the river's function for the disposal of waste.
\end{abstract}

Keywords Long-term socio-ecological research · Urban metabolism · Environmental history $\cdot$ Danube $\cdot$ Vienna $\cdot$ Socio-metabolic transition

Electronic supplementary material The online version of this article (doi:10.1007/s12685-013-0075-1) contains supplementary material, which is available to authorized users.

\footnotetext{
S. Gierlinger $(\bowtie) \cdot$ S. Gingrich · F. Krausmann

Faculty of Interdisciplinary Studies (IFF), Institute of Social Ecology Vienna, Alpen-Adria University

Klagenfurt, Schottenfeldgasse 29, 1070 Wien, Austria

e-mail: sylvia.gierlinger@aau.at

G. Haidvog1

Institute of Hydrobiology and Aquatic Ecosystem Management (IHG), University of Natural Resources and Life Sciences, Vienna (BOKU), Max-Emanuel-Straße 17, 1180 Vienna, Austria
} 


\section{Introduction}

Abel Wolman (1965) was the first to argue that cities have a metabolism: for their functioning they require large amounts of materials, energy and water; all of these resource inputs, ultimately, also leave the city again in the form of wastes and emissions. Cities are centres of consumption and the supply and disposal of large amounts of materials and wastes is a key issue for urban development and sustainability. Rivers and, more generally speaking, the whole waterscape including tributaries and groundwater play an important role in urban resource supply and waste disposal-a role that changes over time and in particular during industrialisation.

The conceptual approach of social metabolism emphasizes the link between supply and discharge (Fischer-Kowalski and Weisz 1999; Baccini and Brunner 2012). The amount and quality of wastes and emissions depend on the amount and quality of materials processed and consumed in the city. Long term socio-ecological research describes fundamental changes in the quantity and quality of material and energy use as socio-metabolic transition (Fischer-Kowalski and Haberl 2007; Singh et al. 2013). Since its introduction, the metabolism concept has been widely used in studies on urban sustainability (see e.g. Kennedy et al. 2007 or Weisz and Steinberger 2010 for an overview) and increasingly also in urban environmental history (Tarr 2002; Douglas et al. 2002; Barles 2005). Most historical studies have focused on changes in urban metabolism during industrialisation and explore the development of urban resource supply and discharge in relation to urban growth, economic development and technological change. Recent studies have, for example, investigated the long-term development of urban energy use (Krausmann 2013; Kim and Barles 2012), inputs and outputs related to urban food consumption (Barles 2007a; Schmid-Neset 2005), urban water metabolism (Tello and Ostos 2012) and the flow of substances such as nitrogen (Barles 2007a; Billen et al. 2009) or metals (Lestel 2012) through urban systems. Another aspect closely linked to the role of rivers in urban metabolism is the changing technical infrastructure for provision and disposal (see Tarr 1996, Melosi 2000). While the significance of rivers for urban metabolism, for example as a means of transport for urban supply (Gingrich et al. 2012), as a provider of drinking and process water and water power or as a sink of discharge (Billen et al. 1999) is often mentioned, systematic investigations of the interrelations between rivers and urban metabolism are largely missing. Often a narrative of continuous river degradation is presented (Tarr 1996). Others go beyond a pollution narrative. Barles (2007b), for example, is interested in the different aspects of the interrelation of urban metabolism and river systems in the case of Paris and the Seine. Drawing on socio-metabolic transition research (Haberl et al. 2011, Fischer-Kowalski and Haberl 2007), this study takes a similar approach and investigates the transformation of the urban waterscape in the city of Vienna during the nineteenth century from a metabolism perspective. It focuses on the close but changing mutual relation of urban metabolism, urban development and the river Danube.

The city of Vienna is an interesting case for investigating the changing role of rivers for urban metabolism. In the 19th century, Vienna experienced rapid growth in population, which led to not only a fast-rising demand for food, energy and other resources but also changing requirements for the disposal of growing amounts of wastes, waste water and excrement. The river Danube and its tributaries connect the city with its hinterland. For centuries the Danube has been a core transport route and played a vital role for the urban supply of bulk resources like food, feed and wood. Unlike the case of many other urban rivers in the nineteenth century, in Vienna the water of the Danube was in general not used for the supply of drinking water. But the Danube and its waterscape have been of major 
importance for cleaning the city of its metabolic outflows and for disposing of wastes and excreta. With urban growth, industrialisation and technological change ${ }^{1}$ in the nineteenth century, the role of the waterscape for urban supply and discharge has been transformed. This paper investigates the changing significance of the riverscape for Vienna's metabolism.

But it was not only the role of the river and its tributaries for urban metabolism that changed - the waterscape itself was transformed by human intervention during this period of urban growth. Here we focus on two processes and institutions involved: The Great Danube Regulation and the stepwise integration of elements of the urban waterscape into the sewage system. In the 1870s, the course of the Danube in Vienna was changed fundamentally. We see this massive regulation project as a cornerstone in the industrialising city-river relationship, shaping arrangements and consecutive practices along the river. We ask how the perception of the Danube and its role for provision and disposal was reflected in the Danube Regulation Commission's discussions and programme. During the nineteenth century, most of the tributaries running through the city were channelized and tunnelled and thus transformed into invisible sewer lines. After the introduction of the alpine water pipeline, the already existing sewage system was transformed into an integrated waterborne sewage system stretching through the whole city. This development was driven by sanitary considerations.

This article is structured in three main parts. The first section provides background information on geography and the development of Vienna and the Danube in the nineteenth century. The next section investigates the role of the Danube for the transportation of goods into the city and the changing significance of river transport for urban supply. The third part is concerned with the changing role of the urban waterscape as a sink for discharge. It discusses the debates about alternative disposal systems and actual changes in the disposal infrastructure and presents an estimation of the increasing amount of organic matter and nitrogen discharged into the urban waterscape (and its implication for river quality) between 1830 and 1910 . In the final section we summarise the main findings and draw some conclusions on the changing role of the urban waterscape for the metabolism of the city during industrialisation.

\section{Vienna and the Danube during the industrial transformation}

Vienna is situated in the easternmost foothills of the Alps. Terrain elevation ranges from $542 \mathrm{~m}$ above sea level to $149 \mathrm{~m}$ above sea level (Embleton-Hamann 2009). Many streams originate from the hilly Vienna Woods (Wienerwald) region in the western part of the city (see Fig. 1). These creeks run through the city and discharge into what is now called the Donaukanal, the southernmost branch of the Danube, which has been the connection of the city with the distant main arm of the river Danube for centuries (Fig. 1). In Vienna the Danube still shows characteristics of a mountain river (Pasetti 1862). It has a dynamic water level with the highest level between spring and early summer due to the snowmelt in the Alps (mean water in Vienna c. 2,000 $\mathrm{m}^{3} / \mathrm{s}$, centennial average flood: $8,500-11,000 \mathrm{~m}^{3} / \mathrm{s}$ ). The lowest water level is in January $\left(600-900 \mathrm{~m}^{3} / \mathrm{s}\right)$. Flood events can happen throughout the year (Hohensinner et al. 2013, in this issue). This specific geographic and

\footnotetext{
1 We understand technology in a very broad sense, including the knowledge or technique needed for the production and use of the technological "hardware" (Grübler 1998).
} 


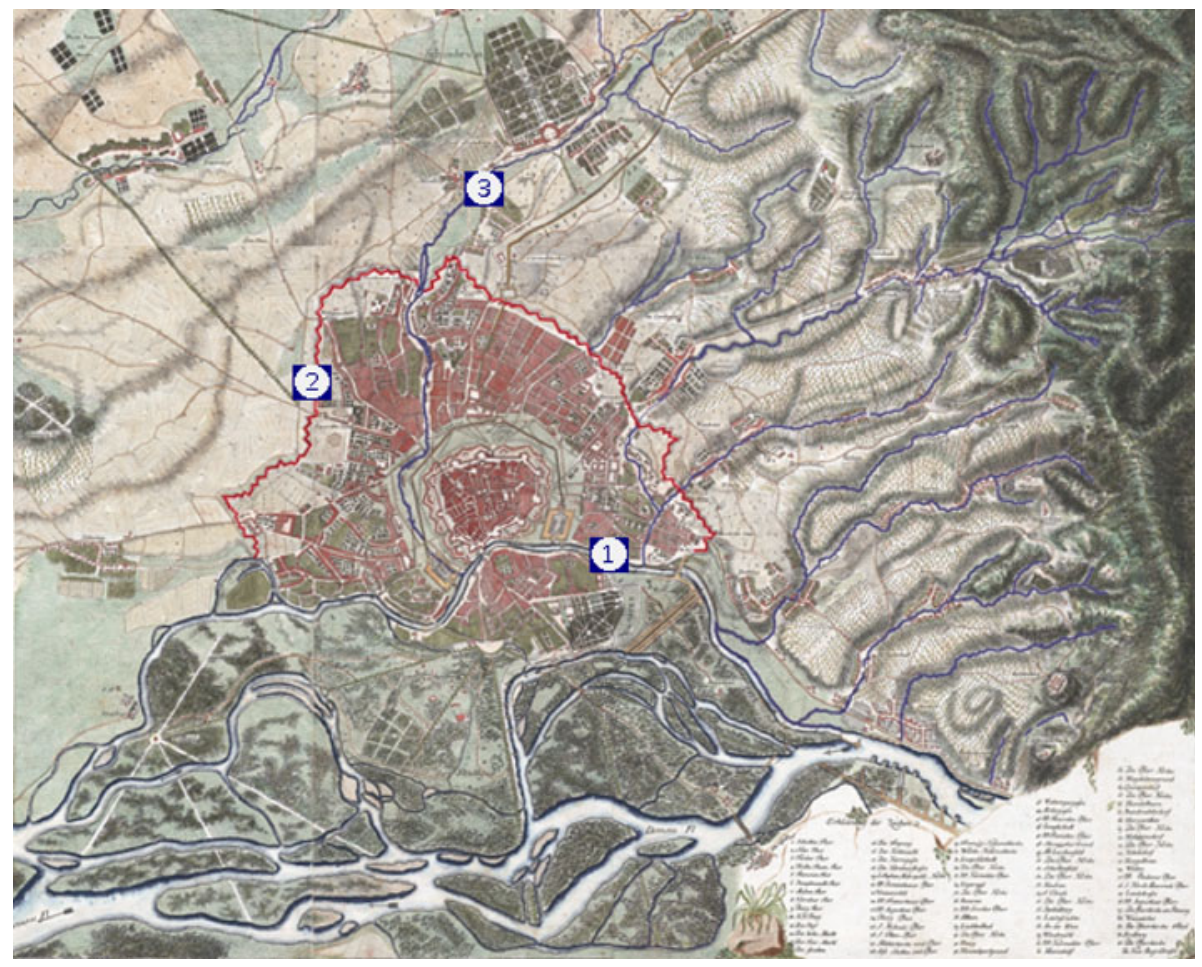

Fig. 11 Donaukanal, 2 Linienwall, 3 Wienfluss. Vienna and its urban waterscape around 1770. The map is oriented towards the south-east and shows the location of the Linienwall (2), a fortification which served also as the tax boundary, and that Vienna is connected to the main arm of the Danube only via the southernmost branch of the Danube, the so-called Donaukanal (1). A system of streams originating from the Vienna Woods in the west of the city, including the Wienfluss (3), discharges into the Donaukanal. Source: based on the "Topohydrographic map of Vienna and its surroundings" from Francois Joseph Maire (1788), Copyright Wien Museum (graphically edited by the first author)

geomorphological situation of the Viennese Danube is the basis for any intervention into the urban waterscape.

Vienna, the capital of the Habsburg Empire, underwent major changes in the nineteenth century. Population growth, industrialisation and the energy transition from biomass to coal drove fundamental transformations of practices and arrangements along the river. Population numbers rose from 230,000 around 1,800 to slightly more than 2 million inhabitants in 1910 (see Fig. 2). ${ }^{2}$ These numbers refer to changing administrative boundaries. The territory of the city was expanded in several steps to its present size (Krausmann 2013). Until 1850, the city had an extension of only around $2.8 \mathrm{~km}^{2}$, which corresponds nowadays to the historic inner city (district I). But already from 1704 on, the tax border, the so-called Linienwall (Vienna Lines), also included the suburbs of the city.

\footnotetext{
${ }^{2}$ In this paper we use population numbers from various censuses between 1800 until 1910. A systematised census that meets current standards was introduced not until 1869 (Weigl 2000). Prior to this, population numbers were usually accounted for military purposes. This had the effect that those who were not important for military purposes were not accurately counted. In the statistical yearbooks of Vienna, revisions of the military conscriptions were listed. Until 1850, numbers relate to the population at the beginning of the year, from 1852 until 1910, they relate to the population at the end of the year (MSW 1900, 1910).
} 
Fig. 2 Population numbers for Vienna within its current boundary and within its changing boundaries in the years 18001910. Source MSW (1883-1913), Weigl (2000)

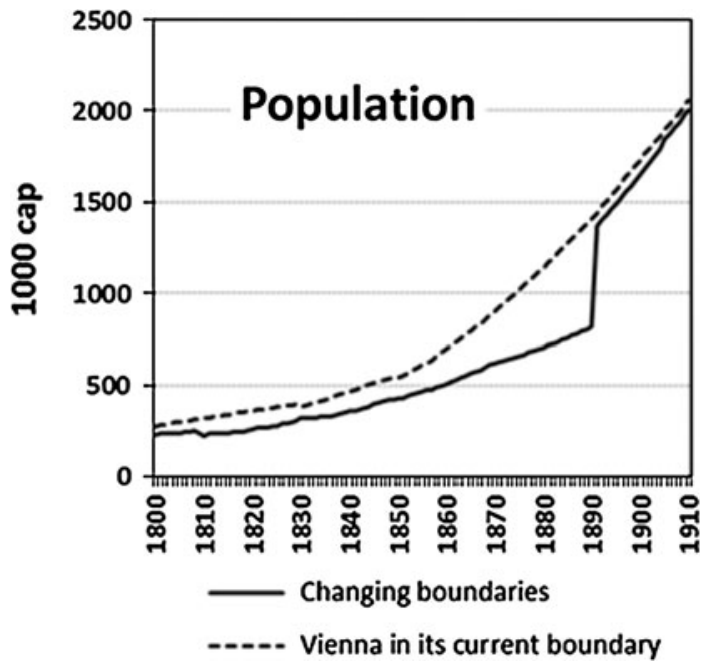

This comprises an area of around $60 \mathrm{~km}^{2}$. In 1890 the city grew to an area of around $178 \mathrm{~km}^{2}$ and population numbers jumped up to approximately 1.3 million inhabitants (see Fig. 2). By 1913, the city had grown to cover $278 \mathrm{~km}^{2}$ (MSW 1913). Even though the area outside the city tax boundary is not included in the statistical records of the city of Vienna before 1890 , the villages were increasingly integrated into the urban system and a growing population needed food and other products and produced waste. Figure 2 displays population numbers for Vienna within its current boundary and with the contemporary administrative borders. Statistical records on the supply and data on the disposal system in contemporary nineteenth century sources usually refer to an area within the city tax boundary before 1890 and include the suburbs from that date on. For this reason we chose to refer data on the supply and disposal presented in this paper to changing administrative borders.

In the nineteenth century population growth together with industrial development drove a rapid increase of the city's resource demand. Although Vienna never emerged as a centre of heavy industries, new industries and modes of production based on coal and the steam engine changed the city. In particular the construction of the first steam-driven railway in the Austrian Monarchy beginning in 1830 triggered the establishment of machine factories, which is seen as a cornerstone in the industrialisation process in Vienna (Czeike 2004). Urban growth and industrialisation went hand in hand with a transformation of the city's metabolism, a transformation that had far reaching effects on arrangements and practices along the Viennese Danube. In the nineteenth century, Vienna underwent a transition from a mainly biomass-based energy system to the large scale use of coal (see Fig. 3). The share of biomass in urban energy supply declined rapidly from more than $95 \%$ in 1840 to around $25 \%$ at the turn of the century (see Fig. 3). Vienna's energy transition (see Krausmann 2013) resulted in an enormous increase in urban energy use. ${ }^{3}$ Energy use in the

\footnotetext{
${ }^{3}$ Energy use in this paper refers to the indicator DEC (Domestic Energy Consumption). This indicator is derived from socio-ecological energy flow accounting (Haberl 2001) and accounts for all primary energy used in a specific socio-economic system (in our case, the city of Vienna) in one year, including all energy carriers (such as food, feed, fuelwood, hydro power or fossil fuels) and all societal activities (such as heating, transportation, industrial use, and feeding humans and working animals).
} 


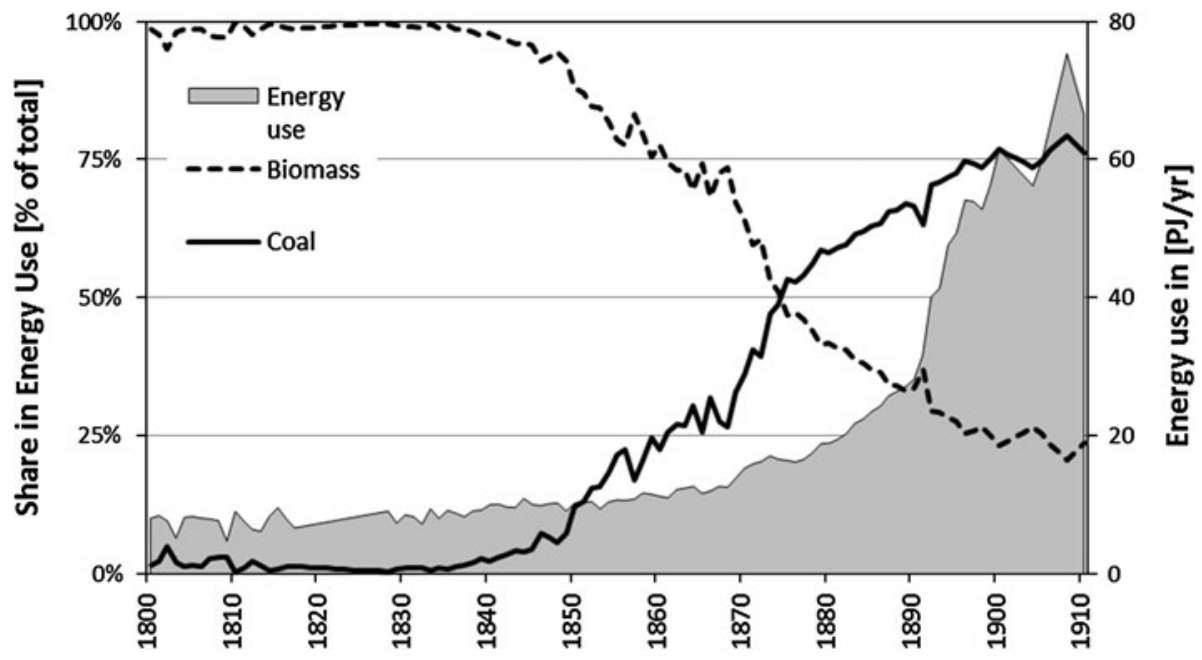

Fig. 3 Energy use in the city of Vienna, 1800-1910: energy use in PJ/year and the share of biomass and coal in total energy use. ( 1 Joule $=0.24$ calories, $1 \mathrm{PJ}=10^{15} \mathrm{~J}$ ). Source based on data in Krausmann 2013

city increased by roughly one order of magnitude and reached more than 60 PJ in 1910 (see Fig. 3), with coal accounting for $75 \%$ of overall energy use. The socio-metabolic transition had far-reaching effects on the river-city relationship. With the availability of new forms of energy and the technology to use this energy, the greatest transformation of the Danube in Vienna so far became possible: the Great Danube Regulation between 1870 and 1875 (see Hohensinner et al. 2013, in this issue).

\section{Supplying the city}

Urban resource supply and river transport

With increasing population numbers and urban development in the nineteenth century, the size of Vienna's metabolism multiplied. Figure 4 shows the development of inflows of major bulk materials into the city. Except for wood, which peaked around 1840 at $490 \mathrm{kt} /$ $\mathrm{yr}(\mathrm{kt} / \mathrm{yr}=$ kilotonnes per year) and then began to decline, the input flows of all materials multiplied in the nineteenth century. By 1910, coal consumption had increased from almost zero at the beginning of the nineteenth century to 2.2 mio tons per year. The deliveries of food and feed grew from $135 \mathrm{kt} / \mathrm{yr}$ in 1830 to $460 \mathrm{kt} / \mathrm{yr}$ in 1910 . The inflow of building materials (bricks, stones, sand and lime), for which data are only available for the period 1830-1873, grew from 160 to $820 \mathrm{kt}$ per year, with a peak of 1.5 mio tons in 1870 . In the four decades between 1830 and 1870, a period for which reliable data for the supply with most bulk materials are available from tax records (Hauer 2010), the overall volume of wood, coal, food, feed and building materials brought into the city roughly tripled from $700 \mathrm{kt} / \mathrm{year}$ to almost 2.1 million tons/yr. Supplying the growing city with sufficient resources was a major challenge. Every day several thousand tons of goods and raw materials had to be transported from more or less distant regions to urban consumers. Traditionally, the Danube was the key transport route for these inflows. While the capacity for overland transport in carriages was only around one to four tons per carriage, that for 


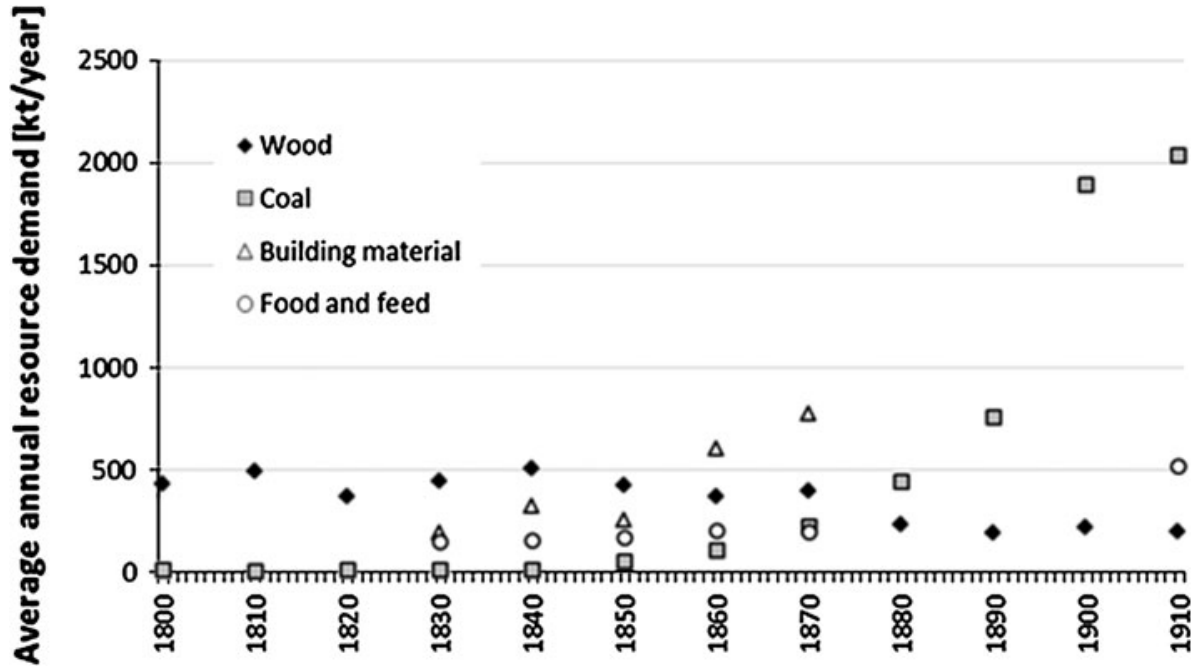

Fig. 4 Development of material use in the city of Vienna from 1800 to 1910 . Average annual inflow (three year averages) of major resource groups: wood, coal, building material, food and feed $(1 \mathrm{kt}=1,000 \mathrm{t})$. Calculated from data collections in Krausmann 2013 (wood and coal) and Hauer 2010 (building materials, food and feed)

water transport on floats or rowing boats (Plätten) ranged from 10 to around 100 tons and since the second half of the nineteenth century steamships offered transport capacities of several hundred tons (Winckler 1870). But transport on the Danube was subject to considerable fluctuations related to high or low water level or ice jams in the winter months, and transport was generally restricted during the months December to March (Pasetti 1850).

The Danube kept its important role for urban supply throughout the nineteenth century as a whole, but the proportion of river transport for supplying the city changed over time. The energy transition and the development and implementation of the steam engine in the nineteenth century went hand in hand with the second transport revolution (Möser 2004), which can be described as a transition from muscle power (human and animal labour), wind power or gravity-driven transport to the dominance of steam power used for steamships and railways. The first steamship on the Danube (named "Franz I" after the Habsburg emperor) left Vienna on a journey towards Budapest on 17 September 1830 (Göbl 2008). The significance of steamboat transport for river transport remained low until the 1850s. Figure 5 shows the total amount of materials (food, feed, wood, construction material, goods) transported to Vienna on the Danube both downstream and upstream between 1835 and 1910 via steamships ${ }^{4}$ and rowing boats. The total amount of materials imported on the Danube more than doubled in this period. Before 1850, the share of steamships was rather small; in 1868 it contributed around $40 \%$ of total river freight, rising to around $70 \%$ by 1910 .

\footnotetext{
${ }^{4}$ Figure 5 comprises data from the Donau Dampfschiffahrtsgesellschaft (DDSG), Süddeutsche Donau Dampfschiffahrtsgesellschaft (since 1888), Ungarische Fluß- und Seeschiffahrtsgesellschaft (since 1893) and the Raaber Dampfschiffahrts Aktien Gesellschaft (1888-1892).
} 


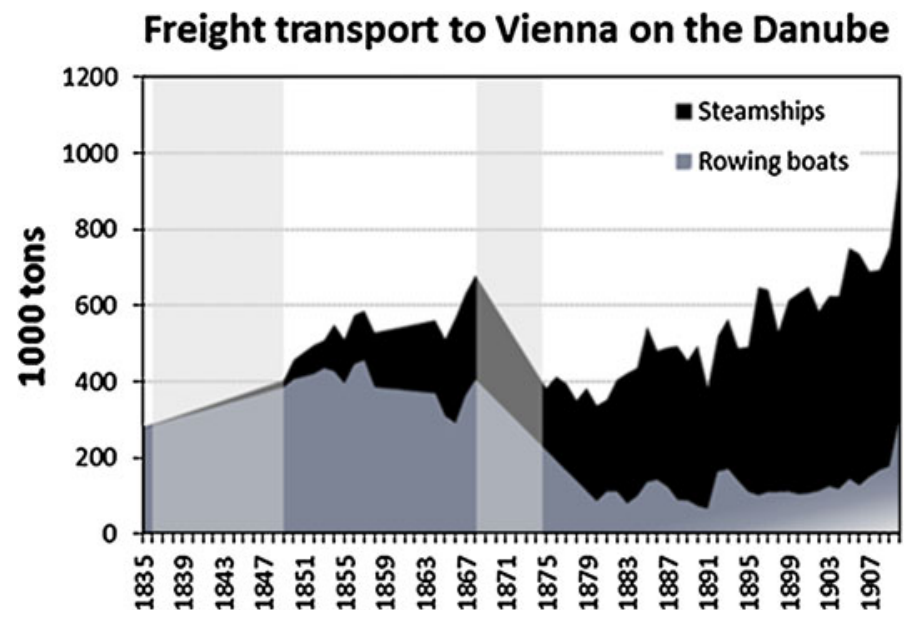

Fig. 5 Total mass of goods disembarked at the Danube harbours of Vienna in the years 1835 and 1910. Shaded areas mark interpolations for years with incomplete data. Note the mass of goods transported on rowing boats is likely to represent underestimates for the years 1875-1910, due to missing information on the mass of wood products. Sources Winckler (1870) for the years 1835-1868, MSW 1884, 1887, 1892, $1897,1902,1907,1910$ for the years $(1875-1910)$

\section{Steamships and the Danube regulation}

Throughout the nineteenth century, comprehensive river regulation projects for the Danube and the Donaukanal were discussed (Thiel 1906; Michlmayr 1994, DRK 1868). Before the Great Danube Regulation in Vienna, the river had many arms, some of them meandering through a vast floodplain area (Fig. 1). The highly dynamic riverine landscape changed its configuration with every flood and in particular during ice jams. The changing water levels and water courses posed challenges for shipping and thus for continuously supplying the industrialising city with energy and raw materials. The regulation of the Donaukanal was initially the main goal of regulation projects in the nineteenth century. The Donaukanal connected the river with the city. Its navigability was important for shipping food, fuel wood and building materials from up- and downstream into the city. The Donaukanal was unsuitable for steamship navigation, which was restricted to the main arm of the Danube. The first two landing places for steamships near the city were set up at Nussdorf, close to the outlet of the Donaukanal and close to Kaisermühlen. Later a third landing place was opened in the vicinity to Floridsdorf, together with a shipyard (Smital 1903). These landing places were several kilometres away from the city, which was problematic for both freight transport and passenger traffic. Freight as well as people had to be transported to and from town, either by smaller boats on the Donaukanal or via roads and later railways (Meidinger 1861).

In the course of the nineteenth century, the use of steam boats increased (see Fig. 5) and regulation of the main arm of the Danube river became more important for shipping (Winckler 1870). Several Danube Regulation Commissions were constituted before the Great Regulation began in 1869/70. The first of these was established in 1849 by the then minister for commerce, trade and public infrastructure ("Minister für Handel, Gewerbe und öfentliche Bauten"). Its task was to formulate a programme for the regulation. This commission's main targets were to stabilise the bed of the main Danube arm in order to facilitate the construction of a solid bridge and at the same time to protect the city from 
flooding (Pasetti 1850). Because of the low amount of freight brought via steamboats, the Donaukanal continued to serve as the most important transport route for food and wood to the city into the 1850s (Gingrich et al. 2012). Hence the first Danube Regulation Commission (DRC) considered the regulation of the Donaukanal as important as the regulation of the main arm. The main intention was to transform the channel into an artificial shipping canal and to improve flood protection. The programme of this commission was not realised.

The second Danube Regulation Commission was constituted in 1864 after a flood in 1862. The aims of the regulation were debated among the Commission's members. The programme of a subcommittee of this commission formulated the main aims of the regulation project: it should alleviate navigation obstacles, protect the city and its inhabitants from flooding and make the construction of a stable bridge across the river possible (DRC 1868). Central to the debates within the commission was the question of where the Danube's new main course should be located and whether the construction of a completely new and straight river bed was advisable or not. According to the DRC (1868), a single channel with flood protection dykes would allow all side arms to be cut off, to protect the surrounding area from flooding as well as to prevent shallow water conditions, so that navigation by steamboats and other ships with a higher draft would always be possible. In general, it was recommended that all obstacles for shipping should be abolished (DRC 1868 , p. 65). The idea of concentrating the river into a single, artificially excavated cut-off and disconnecting side arms and oxbows was first put forward by the director of the imperial building council (Hofbauratsdirektor) Schemerl in 1810 (Thiel 1906; Pasetti 1850), while at the same time renowned engineer J. G. Tulla formulated a similar principle for the Rhine regulation (Blackbourn 2006).

In contrast to most of the suggestions made previously for regulating the Viennese Danube, the Donaukanal was of minor importance for the second DRC. The subcommittee argued that the needs of industry, commerce and trade would make the concentration of regulation on the main arm necessary. They acknowledged that the Donaukanal was the most important transport route for providing food for the city as far as traditional river transport on floats or row boats was concerned. But they were also convinced that with an increasing use of steamboats for the transportation of goods, the centre of trade should and would concentrate on the main arm of the Danube (DRC 1868, p. 15). They based their assumptions on the increasing volume of grain transported by ship on the Danube (DRC 1868, p. 58). The second DRC also promoted the need to connect different means of transport, noting that the harbours had to be linked to railway stations and roads in order to transport goods to the city centre.

The subcommittee's programme was finally accepted by Emperor Franz Joseph I and in 1869/70 construction works began. Most side arms, except for the Donaukanal, were cut off and a straight riverbed was constructed. In the meetings and negotiations of both commissions, questions of provision and disposal relating to the city were issues of debate. The actual regulation in the 1870 s transformed the course of the river and changed the whole waterscape fundamentally (see Hohensinner et al. 2013, in this issue).

\section{River or rail: the disappearance of wood rafting along the Danube}

Despite the fact that river transport retained its importance throughout the nineteenth century, railways were a hitherto unknown competitor, connecting the city to new hinterlands (Gingrich et al. 2012). In 1837, work on the first Austrian steam railway started, connecting Vienna to the important coal mines in Moravia. The connection to Ostrawa and 
(a)

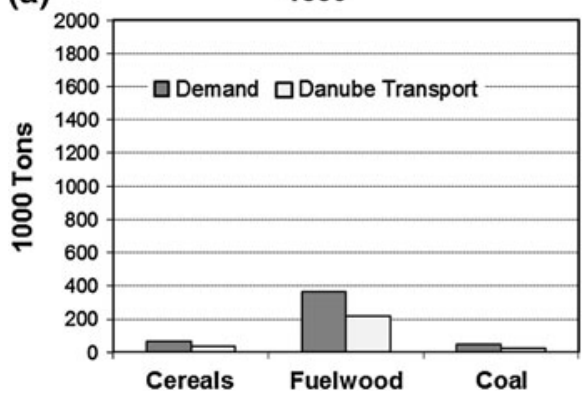

(b)

1900

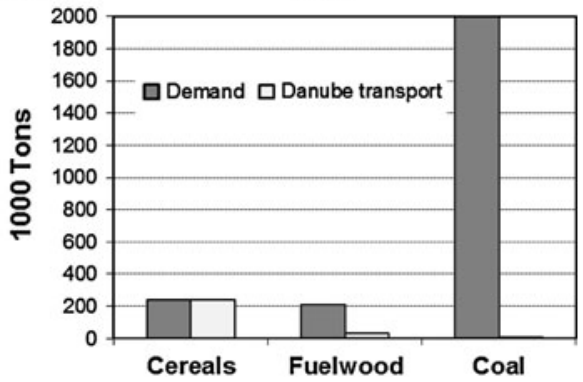

Fig. 6 Comparison of Danube transport and the demand of cereals, fuelwood and coal in 1850 and 1900. Sources data on demand for 1850 from Hauer (2010), for 1900 from Krausmann (2013), data on the Danube transport for the year 1850 from Winckler (1870), for 1900 from MSW (1900)

Bohumin, where the railway company owned large coal mines, was completed in 1847 (Foetterle 1870). The change in the energy system from fuel wood to coal favoured railway transport as there were no navigable waterways connecting the city and the large coal mines of the Austrian and Austro-Hungarian monarchy in the north (Krausmann 2013). As shown in Fig. 4, wood was still the main fuel in 1850 and the most important material transported to Vienna on the Danube (see Fig. 6). Almost $60 \%$ of the wood burned in Vienna was shipped to urban markets via the Danube while the remaining part was brought via land on horse-drawn carts. By 1900, the demand for fuel wood had decreased and the share of river transport was negligible. The main energy source was coal, which to a large extent reached Vienna via rail transport (MSW 1883-1913), yet the share of coal brought by ship amounted to only $3 \%$ of total input. The Danube almost completely lost its importance for the provision of energy sources for the city.

The competition between river and rail transport is not simply a story of substitution. The importance of river transport for the provision of the city declined after a peak in 1868 (see Gingrich et al. 2012), but this decline did not occur equally for all materials. For provision with cereals in particular, river transport remained important. Even in 1900, almost all of the city's cereal demand was met by river transport (see Fig. 6).

Although the changing role of different transport means for the provision of the city would have to be studied in relation to more goods and in more detail to make a final and well-founded conclusion, it can be assumed that river transport was not simply replaced by railways but lost its role especially when the location from which goods were sourced was not connected via water ways. While in many other European countries artificial navigation channels established connections to supply regions without natural waterways, all plans to build navigation channels for Vienna - such as that of Vogemont from the beginning of the eighteenth century—failed (Riebe 1936; Helmedach 2002, Vogemont 1713).

\section{Cleaning the city}

Rising outflows: pollution vs. valuable resource

The surging development of urban metabolism not only meant a multiplication of resource inflows, it also resulted in an increasing amount of waste and emissions. All materials 
entering the city are sooner or later transformed into waste and emissions. ${ }^{5}$ The largest part of all urban outflows are emissions to air from combustion and respiration, but with industrialisation an increasing amount of wastewater from households and industry accrued, which was discharged into the urban waterscape in Vienna (Kortz 1905). With rising population numbers in the nineteenth century, not just the mass of food and feed consumed in the city increased, but also the amount of faecal matter and sewage multiplied. Assuming that a single human excretes around $130 \mathrm{~g}$ of solid faecal matter and $1,200 \mathrm{~g}$ of urine per day ${ }^{6}$ (Hitschmann and Hitschmann 1920), in the year 1830 around 420 tons of human excrement had to be disposed of each day in Vienna. In the year 1910 this amount rose to more than 2,600 tons of excrement per day.

Excrement mostly consists of organic matter and water, but also contains nitrogen, phosphorus and other valuable plant nutrients. In the nineteenth century, nitrogen as a resource was much-debated among agriculturalists and chemists in Vienna and other European cities (see Liebig 1840; Winiwarter 2000; Barles 2007a). The German agricultural chemist Justus von Liebig argued that the nutrients removed from the soil due to harvesting must be returned in order to maintain soil fertility (Liebig 1840). As cities continued to grow throughout the nineteenth century, more nitrogen was withdrawn from the agricultural hinterland. Agriculturalists in Europe and also in Austria called for the collection of urban excreta and the production of human fertiliser. The Chamber of Commerce in Vienna, for example, complained about the loss of fertiliser in urban excreta that was discharged into the waterscape (Handels- und Gewerbekammer 1867). As in many other cities, there were plans to build sewage farms close to Vienna (Fürst 1863; Podhagsky 1892; Wodicka 1900), but none of these projects were ever realised. In Vienna, most human excreta were simply discharged into the urban waterscape throughout the nineteenth century, often with considerable environmental impact (see below). In addition to household excreta, commercial and industrial waste and wastewater was a source of organic matter and toxic substances. Billen et al. (1999) estimated the nutrient load in river systems from early industrial inputs. They concluded that in Western Europe in the late nineteenth century, traditional production processes in the textile industry, tanneries, candle factories and other industries generated the dominant part of the nutrient load in rivers (see also Steinberg 1991; Weyl 1897). The same may be true for Vienna and its waterscape. During the nineteenth century, there was a considerable food and textile industry (Chaloupek et al. 1991). Almost throughout this period, contemporaries complained about the discharge of waste and wastewater from tanneries, butcheries, dyeing mills, breweries and others into the Wienfluss or Donaukanal (Pollak 1912; WSTP 1864-1913).

The increased amount of excrement and industrial wastewater that was discharged untreated intensified the pressure on aquatic ecosystems. Bacteria require oxygen for the decomposition of organic matter in water. Nitrogen and other nutrients (mainly phosphorus) fertilise the water and cause algal growth. When these algae die, even more organic matter needs to be decomposed. The decomposition of organic matter requires oxygen, and high concentrations of organic matter can result in a reduction of the oxygen content of the water to levels that will not permit the life of heterotrophic organisms

\footnotetext{
5 Food, feed, fuelwood and coal are usually consumed and transformed into waste and emissions within a short period of less than a year; other materials, such as timber or construction materials accumulated in buildings and urban infrastructures, can remain for many decades; ultimately, however, all inflows leave urban systems again as wastes or emissions.

${ }^{6}$ Fresh weight.
} 
(McNeill 2000). With industrial wastewater, toxic substances were also discharged into the waterscape (WSTP 1864-1913). For contemporaries, hygienic issues related to urban outflows were important. Excrement is a transmitter of pathogens. Throughout the nineteenth century, sanitary concerns were considered to be problematic by urban health authorities. This triggered major changes in the disposal system. At the beginning of the 20th century, a unified waterborne sewage system was installed, which discharged most of the urban sewage at one spot into the Donaukanal. Two distinct phases in the evolution of the sanitation system can be identified in the nineteenth and early twentieth century.

\section{Patchworked disposal system}

By 1830, cesspools were already of minor significance and more than $80 \%$ of the houses within the tax boundary (Linienwall) of the city were connected to sewers (Kohl 1905). Compared to other cities such as Paris (Barles 2007a) or Linköping (Schmid-Neset 2005), this was a high rate. The disposal system at that time was a patchwork of open channels and streams as well as underground sewers (Kohl 1905). As early as 1706, house owners of the city were urged by an imperial decree to connect the lavatories of their houses to the sewers and the cesspools were only allowed to be cleaned during winter (Payer 2005). In 1833 , around $115 \mathrm{~km}$ of street sewers existed (Kohl 1905). This was at a time when there were no flushing toilets and almost no water pipes connected to the houses. A functioning sewage system requires water in order to flush excrement and other substances away; otherwise the waste accumulates in the sewers. The early significance of the sewer system in Vienna was closely related to the specific geomorphological situation of Vienna: Originating in the Vienna Woods, several small streams traverse the city and drain into the Donaukanal (Figs. 1, 7) and provided a natural basis for the early sewer system.

At the beginning of the nineteenth century, people commonly allowed excreta, dead animals and all kinds of wastes into these streams or directly into the Danube (Kohl 2002). With urban expansion, these streams were increasingly integrated into the sewer system. The kinetic energy of the small streams was used to flush urban excreta out of the city and into the Danube. This disposal system, however, was not without problems, in particular in a rapidly growing city. The water flow in the natural sewers was far from continuous and often was not sufficient to flush away the wastes. Often excreta and waste stayed in the sewers for weeks, as urban health authorities complained (WSTP 1866). Several decrees concerning regulations of when and where to clean the sewers, to remove the nightsoil from the still existing cesspools or to throw rubbish into the streams or the river illustrate the problems associated with the patchwork disposal system (Kortz 1902, Kohl 2002).

Another problem was the high permeability of the early sewers. In the first half of the nineteenth century, sewers were typically built of bricks. Over the years these became porous and sewage increasingly infiltrated the ground. There were many unconnected sewers that took the shortest route to the nearest stream. This means that discharge into the streams took place at many points within the city. As a consequence the smaller water bodies within the city like Ottakringerbach or Wienfluss were heavily polluted (Kohl 1905; Pollak 1912). After flood events, faeces and waste were flushed back into the streets, into the porous sewers and into the cellars of the houses. Already in 1792 and again in 1822, a commission called for the building of intercepting sewers ${ }^{7}$ along the Wienfluss in order to

\footnotetext{
7 Intercepting sewers receive the sewage from several other (smaller) sewers and transport it to the disposal point or to another intercepting sewer.
} 
prevent the outbreak of diseases (Kohl 1905; Payer 2005). Only after the outbreak of the cholera epidemic in the year 1831 did the construction of the intercepting sewers within the "Vienna Lines" begin. Additionally, the streams within the city were one by one channelled through tunnels and transformed into proper sewage channels.

\section{Building a centralised waterborne sewage system}

In 1864 a reorganisation of the public health sector in Vienna took place (Senfelder 1908; Junker 1975). The functions of the public health authority were expanded. From 1864 to 1913, the public health authority also published an annual report documenting its work and the state of health of Vienna's inhabitants. These yearbooks are a rich source for reconstructing the sanitation discourse that took place in Vienna in the second half of the nineteenth century. Debates in Vienna occurred in the context of a European-wide discourse on urban sanitation (Winiwarter 2000). Urban health authorities identified the existing sewage system as one of the main reasons for the high death rates in Vienna (WSTP 1872, p. 9). Alternative disposal systems were discussed, which involved collecting urban excreta in bins or buckets and reusing it as fertiliser or reforming the existing sewage system into a unified waterborne sewage system. The main requirement of a new sewage system in the view of urban health authorities was to remove excreta as quickly and in as undecomposed a state as possible in order to avoid the infiltration of the ground and impurification of the air (WSTP 1872, p. 9).

The public health authority favoured a waterborne sewage system as the option best able to fulfil this requirement. At the same time, it raised concerns about the high water requirement of such a system and doubted that there would ever be enough water in the city to implement this optimal solution in practice. In the first half of the nineteenth century, drinking and process water mainly came from the many wells in the city, although some small water pipelines also existed, bringing water from the streams in the Vienna Woods to the city. In the 1840s, a water pipeline delivering filtrated groundwater was built; however, the demand for clean drinking water could not be met for long by this pipeline supply alone. In 1873, the first long-distance water pipeline (Hochquellenleitung), bringing water from two sources (Kaiserbrunnen and Stixenstein) from alpine regions more than $80 \mathrm{~km}$ south of Vienna, began to supply the city with water (Meissl 2005). Only after the opening of this alpine water pipeline did urban health authorities begin to acknowledge that sufficient water for a waterborne sewage system would be available. The connection of households to the Hochquellenleitung proceeded quickly. In 1879, more than $70 \%$ of Viennese houses were connected to the pipeline (MSW 1883-1913). Water consumption increased enormously in the first decades following the opening of the Hochquellenleitung: from 12 million $\mathrm{m}^{3} / \mathrm{yr}$ in 1876 to 43 million $\mathrm{m}^{3} / \mathrm{yr}$ in 1910 (MSW 1883-1913). The problem of not having enough water for a well-functioning waterborne sewage system was solved. In 1878, systematic flushing of sewers with water from the Hochquellenleitung began (Meissl 2001), while the construction of sewers made of concrete, which were more watertight than the older brick and mortar sewers, also began in the 1870s. However, most of the sewers and streams still discharged at several locations into the Donaukanal and thus deposited an increasing amount of faecal matter into an open watercourse with an unstable water table, running through the very centre of the city.

The first DRC was concerned about these emerging problems: When there was not enough water flowing down the Donaukanal, the water quality started to degrade and a terrible stench was produced as a result. When there was too much water, excreta were 
flushed into the streets, cellars and houses-which posed sanitary problems. This commission called for the installation of flood absorption basins along the stream, which also allowed the flushing and cleaning of the sewers. Again they argued for the collection of urban excreta and for it to be used as fertiliser and deplored the loss of fertilizer for agriculture. As mentioned earlier, the second DRC concentrated on the regulation of the main arm of the Danube. But there was a portion of the commission, known as the "Minorität" (minority) that did not fully agree with the programme proposed by the majority. Among others, a central critique of this group was the way in which the Donaukanal was viewed as being of minor importance. In their view, the regulation of the Donaukanal should be of equal concern since, were it not to be regulated, it would degrade to an open sewage drain with negative consequences for the city. They argued that for sanitary reasons it was necessary to construct intercepting sewers along the Donaukanal synchronous to the Danube regulation. The programme of the majority did include minor works concerning the Donaukanal and eventually this programme was accepted by the minority group. In the course of the Great Danube Regulation in the 1870s, the Donaukanal was dredged mechanically and the riverbanks were raised in height. In Nußdorf, where the canal branches off the main arm, a ship was stationed that could partially block the channel at times of floods or ice jams. When the ship was brought into position, an open gap remained between the ship and the riverbed so that a minimum volume of water could still run into the Donaukanal (Kortz 1905). But variations in the water table of the Donaukanal remained a problem even after the Great Danube Regulation. In periods during which heavy ice floes moved down the river, the gap between the ship and the riverbed became blocked, preventing the inflow of water into the Donaukanal altogether. As a consequence, sewage was not flushed away but remained in the riverbed. In general, there was a higher discharge in the Donaukanal following the Great Danube Regulation (Wex 1876). When there was a high water table, sewage was retained in the sewers. The older sewers made of bricks were not sufficiently watertight and therefore sewage contaminated the groundwater (Kohl 1893). Engineers as well as urban health authorities repeatedly called for the construction of intercepting sewers along the Donaukanal.

Only after the incorporation of the suburbs into the city could the comprehensive regulation of the Donaukanal and the installation of intercepting sewers along the Donaukanal begin. This project formed part of the programme constructing the Viennese public transport system. Urban engineers argued that for the installation of a city railway and harbours along the Donaukanal was necessary to fix the water table and for that a comprehensive regulation of the Donaukanal is necessary (Kohl 1893, P.K 1898). The commission for transportation facilities, founded in 1892 by the state, the city and the province of lower Austria decided to include the installation of intercepting sewers in this regulation project (Meissl and Békési 2005, P.K. 1898).

The construction of new sewers began in 1893 and was finished in 1904. This involved not only building intercepting sewers along the Donaukanal but also extending the sewage system to the suburbs (Kohl 1905). Figure 7 shows a map of the sewage system at around 1900. Most of the former streams (see Fig. 1) were incorporated into the sewage system as intercepting sewers. The waterscape was now integrated to a high degree into the urban infrastructure for discharge. In 1910, urban health authorities announced in their yearbook that the waterborne sewage system, as they had proposed, was now installed (WSTP 1910, p. 154). This sewage system fulfilled their requirement of bringing urban excreta away from settled areas as quickly and in as undecomposed a state as possible. Urban sewage was then discharged untreated into the Donaukanal downstream before it reached the main arm of the Danube. 


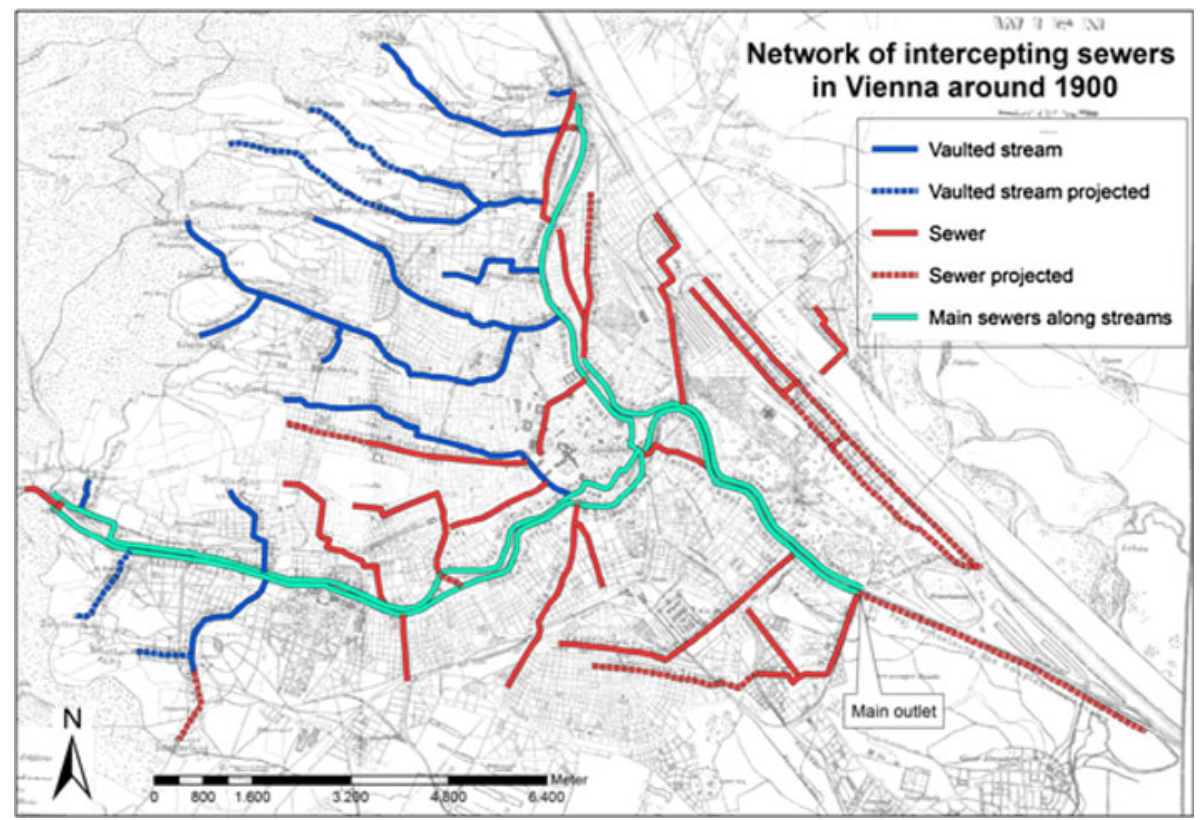

Fig. 7 Map of Vienna's sewage system at around 1900. This shows the network of intercepting sewers. Source based on Kortz (1902)

\section{The impact of discharge on the city and its waterscape}

How much of the organic matter and nitrogen excreted by humans and their livestock was discharged into the waterscape? Was a relevant amount of nitrogen for agriculture "lost" in Vienna's waterscape? What were the implications for the water quality of the Danube and its tributaries?

We estimated the amount of nitrogen discharged from human and animal excrement into the Viennese waterscape between 1830 and 1910 (see a description of the method in the supporting information). The results show that the amount of nitrogen discharged into the urban waterscape increased by roughly a factor of 7 (see Table 1) during the respective time period, rising from slightly more than 900 tons of nitrogen per year in 1830 to around 6,500 tons in 1910 . This was a very significant quantity of valuable plant nutrients, equal to about one-third of the total annual symbiotic nitrogen fixation by leguminous crops in Austrian agriculture (current territory) at that time (see Krausmann 2004). It should be considered, however, that the use of urban excreta as a fertiliser was not unproblematic (see Goddard 1996, 2005; Barles 2007a). On the one hand, the urban health authority was concerned about the transmission of diseases when using urban excrement as a fertiliser in gardens or fields close to settlements. On the other hand, a considerable fraction of nitrogen is lost during the production and transportation of fertiliser produced from human excrement, so the potential result from recycling was significantly lower than the nitrogen contained in excrement. In Vienna, plans to build sewage farms were frequently discussed but never realised. Evidence suggests that farmers were not interested in the use of urban excreta (Handels- und Gewerbekammer 1867). In its report about the situation of agriculture in Lower Austria (the region around Vienna), the Chamber of Commerce 
Table 1 Urban growth and nitrogen discharge from human and livestock excrement in Vienna from 1830 to 1910

\begin{tabular}{lrrrr}
\hline & 1830 & 1873 & 1910 & $\begin{array}{l}\text { Factor } \\
1830-1910\end{array}$ \\
\hline Population & 317,000 & 640,000 & $2,004,000$ & 6 \\
Draft animals & 5,000 & 12,000 & 37,000 & 7 \\
Share of houses connected to the sewage system* (\%) & 85 & 91 & 83 & \\
Mass of urine and faeces excreted by humans (t/day) & 424 & 855 & 2,626 & 6 \\
Nitrogen discharged into the urban waterscape (tN/yr) & 900 & 2,200 & 6,500 & 7 \\
\hline
\end{tabular}

Sources population numbers from MSW (1883-1913); numbers on draft animals from MSW (1912), Sandgruber (1983), Sedlaczek (1891); the share of houses connected to the combined sewage system is from Kohl 1905, WSTP (1864-1913); nitrogen discharged: authors' own calculation

Asterisk for the year 1830, this includes streams and open channels

concluded that the costs for transportation and disinfection of urban sewage would be too high. It further reported that a large livestock population around Vienna, in particular milk cows, supplied sufficient manure for fertiliser production. It can therefore be assumed that there was no particular need for additional fertiliser in the area.

Most urban excreta were instead discharged into the urban waterscape. An assessment of the environmental impact of these nitrogen loads for the water quality for the different water bodies is difficult to produce and is subject to a high level of uncertainty. Some estimates, however, can be made. Around 1830 the amount of nitrogen discharged into the urban waterscape was around 7 times lower than in 1910, but its impact on the water quality of urban surface waters was higher. Excreta and wastewater was disposed of in the many small Danube tributaries within the city. In 1830 around $45 \%$ of the nitrogen discharged landed in Wienfluss, the largest tributary (see Kohl 1905). Pollack (1912) assumes a flow rate at mean water level of $2 \mathrm{~m}^{3} / \mathrm{s}$ around 1830. Based on this assumption we can estimate the nitrogen concentration in Wienfluss. ${ }^{8}$ It suggests that the nitrogen concentration in this tributary was more than six times above present day permissible value. ${ }^{9}$ In the following decades discharge was relocated from the many small streams within the city to the river Danube in the periphery of the city. Based on information regarding the flow rate at mean water level of the Danube in Vienna $\left(2,000 \mathrm{~m}^{3} / \mathrm{s}\right)$ and our estimate of the amount of nitrogen discharged into the river, we calculated the nitrogen concentration in the river water in the year 1910, the year with the highest annual nitrogen discharge rate: the concentration of nitrogen in the main arm of the Danube, when not accounting for the nitrogen input from industry and commerce, would have been significantly below the present day maximum permissible value. When also considering the discharge from industry and commerce, the nitrogen concentration would be considerably higher. But even the double amount of nitrogen discharged would yield a nitrogen concentration below the present day permissible value. Our rough estimate about the water quality of the Danube in Vienna at the turn of the century is in line with a comprehensive study carried out by the Hygiene Institute of the University of Vienna (Brezina 1906). In this study, the water quality of the Danube upstream of the city, in Vienna and downstream

\footnotetext{
${ }^{8}$ And assuming $0.039 \mathrm{gN} / \mathrm{m}^{3}$ in the fresh water, based on the 5 year average between 2003 and 2006 in Nussdorf (personal communication Gerald Wandl).

$90.964 \mathrm{gN} / \mathrm{m}^{3}$ according to Austrian law (Qualitätszielverordnung Chemie Oberflächengewässer).
} 
of Vienna was analysed. The study examined whether it was acceptable to discharge Vienna's sewage into the Danube without treatment. The author concluded that it was acceptable because the self-purification of the river was sufficient for absorbing the sewage. ${ }^{10} \mathrm{He}$ based his assumptions on chemical analyses.

Wastewater discharge had impacts on the water quality of the different water bodies. Firstly, water quality in the smaller tributaries and the Wienfluss was deteriorating. After the outbreak of cholera in 1830, intercepting sewers were installed along the Wienfluss and the streams were incorporated one by one into the sewage system. The problem was then shifted towards the Donaukanal, which had to absorb an ever-increasing amount of wastewater. Sanitary considerations drove the construction of intercepting sewers along the Donaukanal in the last decade of the nineteenth century, after which the wastewater was discharged into the Donaukanal shortly before the point at which it reunited with the main arm of the Danube. This was perceived as unproblematic by contemporaries, because of the self-purification of the Danube. ${ }^{11}$ Present day analyses of nitrogen concentration come to similar conclusions. When returning to the question of why sewage was not used for agricultural purposes in Vienna, another hypothesis could be that the pressure discharge placed upon the receiving river was not as high as, for example, in Paris and the Seine, where sewage farms were built.

\section{Conclusions}

The urban waterscape played an important role in the urban metabolism of Vienna in the nineteenth century - a role that underwent changes during the industrial transformation. The kinetic energy of the river was used for both the transportation of material into the city and the disposal of urban excreta. However, river transport lost significance in a very important area: the supply of the city's most important energy carrier. On the other hand the river's function for the disposal of waste gained in importance. During the transition of the energy system, the proportion of goods transported to the city on the water route declined, whereas the amount of nitrogen contained in wastewater discharged into the Danube rose by one order of magnitude. The urban waterscape itself was transformed fundamentally during the energy transition. Most of the small tributaries running through the city were rearranged and integrated into the urban sewage system. Prevention of epidemics was a major driver for this development. The Danube was comprehensively regulated during the Great Danube Regulation in the 1870s. Most side arms, except for the Donaukanal, were cut off and a straight riverbed was constructed. Considerations and projections about the increasing importance of the Danube as a transport route and Vienna as a centre of trade were main arguments for this massive intervention into the riverscape. For the first DRC (1849-51), regulation of the Donaukanal and halting the direct discharge of sewage were of equal importance with the regulation of the main arm. In the final reports of the second DRC in 1868, there was a strong argumentation that establishing

\footnotetext{
${ }^{10}$ For most of the twentieth century, Viennese wastewater was discharged into the Danube with only minimal treatment. The first comprehensive wastewater treatment plant at the Danube channel was only opened in $1980(!)$.

11 The idea of self-purification of rivers was first formulated in 1869 in England by Letheby (Weyl 1897). He stated that despite urban pollution, rivers return to their original state several miles outside the city where the pollution occurs. This was a controversial idea. Important contributions to this theory came from the German chemist Pettenkofer, who based his assumptions on chemical analyses of the water in the river Isar in and Munich and further downstream from the city (Weyl 1897).
} 
Vienna as a new centre for commerce required a comprehensive regulated water route with staple yards, landing places for ships, a winter harbour and so on. However, questions of regulating the Donaukanal and bringing the practice of direct discharge of sewage into the water to an end were no longer of major concern. In contrast to contemporaries' expectations, the Danube's role as a supply route for the city decreased over time.

Our study shows that the interrelations between Vienna's metabolism and the river Danube underwent far reaching changes during the nineteenth century, when urban resource use and discharge multiplied and the urban waterscape was transformed. Changes in urban metabolism during industrialisation have been investigated for several other industrialised cities. While different in temporal development and distinguished by regional specificities, these changes in urban metabolism pertain to a general pattern described as socio-metabolic transition.

We investigated this transition process from a long-term socio-ecological perspective. To this end, one needs to acknowledge both biophysical and societal factors. For the case of Vienna, we could show that the geographic and geomorphologic situation of the Danube and its tributaries shaped urban development and its impact on the local waterscape. But specific actor constellations and arguments also greatly influenced when and how the waterscape was transformed through river regulation or sewerage construction. An integrated socio-ecological perspective in future research on the long term development of city-river interrelations can help to better understand both the general patterns of transition processes and causes for and effects of different developments in different cities.

Acknowledgments This work was funded by the Austrian Science Fund (projects P22265 "ENVIDAN Environmental History of the Viennese Danube 1500-1890" and P21012-G11 "GLOMETRA Global Metabolic Transition") and by the Social Sciences and Humanities Research Council of Canada. The authors wish to thank Martin Schmid, Severin Hohensinner, Christoph Sonnlechner, Verena Winiwarter, Sabine Barles and the Advisory Board of the ENVIEDAN project for their support and comments on earlier versions of the paper. The authors are grateful to Karl Wögerer and Gerald Wandl from EBS Vienna (main wastewater treatment plant) for their support.

Open Access This article is distributed under the terms of the Creative Commons Attribution License which permits any use, distribution, and reproduction in any medium, provided the original author(s) and the source are credited.

\section{References}

Baccini P, Brunner PH (2012) The metabolism of the anthroposphere, 2nd edn. MIT Press, Cambridge Barles S (2005) A metabolic approach to the city: nineteenth and twentieth century Paris. In: Schott D, Luckin B, Massard-Guilbaud G (eds) Resources of the city: contributions to an environmental history of modern Europe. Ashgate, Aldershot, pp 28-47

Barles S (2007a) Feeding the city: food consumption and flow of nitrogen, Paris, 1801-1914. Sci Total Environ 375:48-58. doi:10.1016/j.scitotenv.2006.12.003

Barles S (2007b) Urban metabolism and river systems: an historical perspective-Paris and the Seine, 1790-1970. Hydrol Earth Syst Sci 11:1757-1769

Billen G, Garnier J, Deligne C, Billen C (1999) Estimates of early-industrial inputs of nutrients to river systems: implication for coastal eutrophication. Sci Total Environ 243(244):43-52

Billen G, Barles S, Garnier J, Rouillard J, Benoit P (2009) The food-print of Paris: long-term reconstruction of the nitrogen flows imported into the city from its rural hinterland. Reg Environ Change 9:13-24. doi: 10.1007/s10113-008-0051-y

Blackbourn D (2006) The conquest of nature: water, landscape and the making of modern Germany. Jonathan Cape, London 
Brezina E (1906) Die Donau vom Leopoldsberge bis Preßburg, die Abwässer der Stadt Wien und deren Schicksal nach der Einmündung in den Strom. Z Hyg Infektionskr 53:369-503

Chaloupek G, Eigner P, Wagner M (1991) Wien - Wirtschaftsgeschichte 1740 bis 1938. J \& V, Wien

Czeike F (2004) Historisches Lexikon Wien. Kremayr \& Scheriau, Wien

Donauregulierungskommission (1868) Berichte und Anträge des von der Commission für die Donauregulierung bei Wien ernannten Comites. K.K. Hof- und Staatsdruckerei, Wien

Douglas I, Hodgson R, Lawson N (2002) Industry, environment and health through 200 years in Manchester. Ecol Econ 41:235-255

Embleton-Hamann C (2009) Die Landschaften des Wiener Raumes. In: Embleton-Hamann C, Keiler M, Teufl I (eds) Wien-Umweltstadtführer: Einblicke in die Natur einer Großstadt. Böhlau, Wien, pp 11-18

Fischer-Kowalski M, Haberl H (2007) Socioecological transitions and global change: trajectories of social metabolism and land use. Edward Elgar, Cheltenham, Northampton

Fischer-Kowalski M, Weisz H (1999) Society as a hybrid between material and symbolic realms: toward a theoretical framework of society-nature interaction. Adv Hum Ecol 8:215-251

Foetterle F (1870) Das Vorkommen, die Production und Circulation des mineralischen Brennstoffes in der österreichisch-ungarischen Monarchie im Jahre 1868. Selbstverlag der k.k. geologischen Reichsanstalt, Wien

Fürst AAl (1863) Auch eine Lebensfrage von Wien!. Selbstverlag, Wien

Gingrich S, Haidvogl G, Krausmann F (2012) The Danube and Vienna: urban resource use, transport and land use 1800-1910. Reg Environ Change 12:283-294. doi:10.1007/s10113-010-0201-x

Göbl M (2008) Die Anfänge der Dampfschifffahrt auf der Oberen Donau. Dissertation, Universität Wien

Goddard N (1996) "A mine of wealth"? The Victorians and the agricultural value of sewage. J Hist Geogr 22:274-290

Goddard N (2005) Sanitate Crescamus: water supply, sewage disposal and environmental values in a Victorian suburb. In: Schott D, Luckin B, Massard-Guilbaud G (eds) Resources of the city: contributions to an environmental history of modern Europe. Ashgate, Aldershot Burlington, pp 132-148

Grübler A (1998) Technology and global change. University Press, Cambridge

Haberl H (2001) The energetic metabolism of societies, part I: accounting concepts. J Ind Ecol 5:11-33

Haberl H, Fischer-Kowalski M, Krausmann F, Martinez-Alier J, Winiwarter V (2011) A socio-metabolic transition towards sustainability? Challenges for another Great Transformation. Sustain Dev 19:1-14

Handels- und Gewerbekammer in Wien (1867) Statistik der Volkswirtschaft in Nieder-Oesterreich 1855-1866. Leopold Sommer, Wien

Hauer F (2010) Die Verzehrungssteuer 1829 -1913 als Grundlage einer umwelthistorischen Untersuchung des Metabolismus der Stadt Wien. Social ecology working paper 129, IFF Social Ecology, Vienna

Helmedach A (2002) Das Verkehrssystem als Modernisierungsfaktor. Straßen, Post, Fuhrwesen und Reisen nach Triest und Fiume vom Beginn des 18. Jahrhunderts bis zum Eisenbahnzeitalter. Oldenbourg, München

Hitschmann HH, Hitschmann R (1920) Vademekum für den Landwirt. Moritz Perles, Wien

Hohensinner S, Lager B, Sonnlechner Ch, Haidvogl G, Gierlinger S, Schmid M, Krausmann F, Winiwarter V (2013) Changes in water and land: the reconstructed Viennese riverscape from 1500 to the present. Water Hist. doi:10.1007/s12685-013-0074-2

Junker E (1975) Vom Wiener Stadtphysikat zum Gesundheitsamt der Stadt Wien. Wien Med Wochenschr $1-3: 18-23$

Jv Liebig (1840) Die Chemie in ihrer Anwendung auf Agricultur und Physiologie. Vieweg, Braunschweig

Kennedy CA, Cuddihy J, Engel-Yan J (2007) The changing metabolism of cities. J Ind Ecol 11:1-17

Kim E, Barles S (2012) The energy consumption of Paris and its supply areas from the eighteenth century to the present. Reg Environ Change 12:295-310. doi:10.1007/s10113-011-0275-0

Kohl J (1893) Über das Project für den Haupt-Sammelcanal am linken Donaucanal-Ufer in Wien. Zeitschrift des oesterreichischen Ingenieur- und Architekten-Vereins 18:266-270

Kohl J (1905) Die Entwässerung. In: Kortz P (ed) Wien am Anfang des XX. Jahrhunderts. Gerlach \& Wiedling, Wien, pp 193-212

Kohl W (2002) Zur Geschichte von Gewässerverschmutzung und Gewässerschutz seit dem Spätmittelalter. Schriften des Vereins zur Verbreitung naturwissenschaftlicher Kenntnisse in Wien 137-140:223-286

Kortz P (1902) Die Entwässerung von Wien. Tafel III. In: Weyl T (ed) Die Assanierung von Wien. Engelmann, Leipzig

Kortz P (1905) Wien am Anfang des XX. Jahrhunderts. Ein Führer in technischer und künstlerischer Richtung. Gerlach \& Wiedling, Wien

Krausmann F (2004) Milk, manure and muscular power: livestock and the industrialization of agriculture. Hum Ecol 32:735-773. doi:10.1007/s10745-004-6834-y 
Krausmann F (2013) A city and its hinterland: Vienna's energy metabolism 1800-2006. In: Singh SJ, Haberl H, Schmid M, Mirtl M, Chertow M (eds) Long term socio-ecological research. Springer, New York

Lestel L (2012) Non-ferrous metals ( $\mathrm{Pb}, \mathrm{Cu}, \mathrm{Zn}$ ) needs and city development: the Paris example (1815-2009). Reg Environ Change 12:311-323. doi:10.1007/s10113-011-0255-4

Maire FJ (1788) Topohydrographische Karte der Stadt Wien und ihren umliegenden Gegenden. Wien Museum

McNeill JR (2000) Something new under the sun: an environmental history of the twentieth century. Allen Lane, London

Meidinger H (1861) Die großen Ströme 1. Abteilung-Die Donau, Frankfurt am Main

Meissl G (2001) Hochquellenleitungen und Unratsschiffe. Zur Geschichte der Wiener Wasserver- und entsorgung vor 1914. In: Hahn S, Reith R (eds) Umwelt-Geschichte. Arbeitsfelder, Forschungsansätze, Perspektiven. Verlag für Geschichte und Politik, Wien, pp 157-180

Meissl G (2005) Gebirgswasser in Wien: die Wasserversorgung der Großstadt im 19. und 20. Jahrhundert. In: Brunner K, Schneider P (eds) Umwelt Stadt: Geschichte des Natur- und Lebensraumes Wien. Weimar, Böhlau, Wien, Köln, pp 195-203

Meissl G, Békési S (2005) Öffentlicher Verkehr in Wien. In: Brunner K, Schneider P (eds) Umwelt Stadt: Geschichte des Natur- und Lebensraumes Wien. Böhlau, Wien, Köln, Weimar, pp 153-154

Melosi M (2000) The sanitary city. Urban infrastructure in America from colonial times to the present. John Hopkins University Press, Baltimore

Michlmayr F (1994) Geschichte der Donauregulierung in Wien. In: Deutscher Verband für Wasserwirtschaft und Kulturbau e.V. (eds), Historische Wasserwirtschaft im Alpenraum und an der Donau. Verlag Konrad Wittwer, Stuttgart, pp 539-566

Möser K (2004) Prinzipielles zur Transportgeschichte. In: Sieferle RP, Breuninger H (eds) Transportgeschichte im internationalen Vergleich. Breuninger Stiftung, Stuttgart, pp 45-86

MSW Magistrat der Stadt Wien (1883-1913) Statistisches Jahrbuch der Stadt Wien (various years 1883 to 1913)

Pasetti F (1850) Die Regulierung der Donau und der Bau einer stabilen Brücke über dieselbe bei Wien. Allg Bauztg 15:41-137

Pasetti F (1862) Notizen über die Donau-Regulirung im österreichischen Kaiserstaate bis zu Ende des Jahres 1861 mit Bezug auf die im k.k. Staatsministerium herausgegebene Übersichts-Karte der Donau. Wien

Payer P (2005) Unter der Stadt: Kanalisation und Entwässerung. In: Brunner K, Schneider P (eds) Umwelt Stadt: Geschichte des Natur- und Lebensraumes Wien. Böhlau, Wien, pp 274-279

P.K. (1898) Der Sammelcanal am rechten Ufer des Donaucanales in Wien. Zeitschrift des oesterreichischen Ingenieur- und Architekten-Vereins 50:49-53

Podhagsky JV (1892) Die Marchfeldbewässerung und Verwerthung der Wiener Abfallwässer. Selbstverlag, Wien

Pollak G (1912) Verschmutzt-verbaut-vergessen: eine Umweltgschichte des Wienflusses von 1780 bis 1910. Thesis, University of Klagenfurt

Riebe VE (1936) Der Wiener Neustädter Schiffahrtskanal. Geschichte eines niederösterreichischen Bauwerkes von seinem Entstehen bis zur Gegenwart. Bearbeitet nach archivalischen Quellen. Gutenberg, Wr. Neustadt

Sandgruber R (1983) Wiens Energieverbrauch und Energieversorgung in der Phase der Industrialisierung. Magistrat der Stadt Wien, Wien

Schmid-Neset T-S (2005) Environmental imprint of human food consumption: Linköping, Sweden 1870-2000. Dissertation, Lingköping University

Sedlaczek S (1891) Die definitiven Ergebnisse der Volkszählung vom 31. December 1890 in der k.k. Reichshaupt- und Residenzstadt Wien. Statistische Monatsschrift 17

Senfelder L (1908) Geschichte des Wiener Stadtphysikates. Selbstverlag des Verfassers, Wien

Singh SJ, Haberl H, Schmid M, Mirtl M, Chertow M (2013) Long term socio-ecological research. Springer, New York

Smital H (1903) Geschichte der Großgemeinde Floridsdorf umfassend die Orte Floridsdorf, Jedlesee. Donaufeld und das Jedlersdorfer Fabriksgebiet. Im Verlag der Gemeinde, Floridsdorf

Steinberg T (1991) Nature incorporated: industrialization and the waters of New England. Cambridge University Press, New York

Tarr JA (1996) The search for the ultimate sink. Urban pollution in historical perspective. Universty of Akron Press, Akron

Tarr JA (2002) The metabolism of the industrial city: the case of Pittsburgh. J Urban Hist 28:511-545

Tello E, Ostos JR (2012) Water consumption in Barcelona and its regional environmental imprint: a longterm history (1717-2008). Reg Environ Change 12:347-361. doi:10.1007/s10113-011-0223-Z 
Thiel V (1906) Geschichte der Donauregulierungsarbeiten bei Wien II. Vom Anfange des XVIII. bis zur Mitte des XIX. Jahrhunderts. Von der Mitte des XIX. Jahrhunderts bis zur Gegenwart. Jahrbuch für Landeskunde von Niederösterreich 1905 und 1906, pp 1-102

Vogemont L (1713) Teutschlands Wohl-Stand, Oder Vorstellung einer grundmässigen Einrichtung der Handlung, Wie nemblich Solche in Teutschland, durch Schiffreichmachung und Vereinigung derer Flüssen, zu wegen gebracht werden könne. Wien

Weigl A (2000) Demographischer Wandel und Modernisierung in Wien. Pichler Verlag, Wien

Weisz H, Steinberger JK (2010) Reducing energy and materials flows in cities. Curr Opin Environ Sustain 2:185-192

Wex G (1876) Ueber die Donau-Regulirung bei Wien. Zeitschrift des oesterreichischen Ingenieur- und Architekten-Vereins 28:77-88

Weyl T (1897) Flussverunreinigung, Klärung der Abwässer. Selbstreinigung der Flüsse, Gustav Fischer, Jena

Winckler J (1870) Übersicht des Schiffs- und Waarenverkehrs auf der oberen Donau, zu Wien, Linz und Engelhartszell in den Jahren 1849-1869. Mittheilungen aus dem Gebiete der Statistik 14:1-75

Winiwarter V (2000) Where did all the waters go? The introduction of sewage systems in urban settlements. In: Bernhardt C (ed) Environmental problems in European cities in the 19th and 20th century. Waxmann, Münster, pp 105-119

Wodicka W (1900) Die technischen Grundlagen des Projectes für die Verwerthung der Wiener Abfallwässer durch Berieselung des Marchfeldes. Im Selbstverlage des Verfassers, Wien

Wolman A (1965) The metabolism of cities. Sci Am 213:178-193

WSTP Wiener Stadtphysikat (1864-1913) Berichte des Wiener Stadtphysikates über seine Amtsthätigkeit. Braumüller, Wien 